PINTEREST ЯК ЕФЕКТИВНИЙ IНСТРУМЕНТ ПРОСУВАННЯ НЕПРИБУТКОВИХ ОРГАНІЗАЦІЙ В УМОВАХ ТЕНДЕНЦІЇ МАРКЕТИНГУ У СОЦІАЛЬНИХ МЕДІА

\title{
PINTEREST AS AN EFFECTIVE TOOL FOR PROMOTION NON-PROFIT IN TERMS OF MARKET TRENDS IN SOCIAL MEDIA
}

УДК 658.82

DOI: https://doi.org/10.32843/infrastruct52-12

\section{Білик I.I.}

к.е.н., доцент кафедри маркетингу

і логістики

Національний університет

«Львівська політехніка»

Подарин В.P.

студентка

Національний університет

«Львівська політехніка»

\section{Bilyk Iryna}

Lviv Polytechnic National University

Podaryn Anhelina

Lviv Polytechnic National University
В епоху інфрормаційних технологій соціальні медіа набули статусу потужних, швидких та динамічних орорм обміну інформацією. Такі соціальні медіа, як Pinterest, Facebook, Twitter, використовують у буденному житті мільярди людей. У статті розглянуто необхідність маркетингу у соціальних медіа для неприбуткових організацій. Окреслено проблему просування бренду у соціальних медіа. Проаналізовано ефективність недооціненоі соціальної медіамережі Інтернет-сервісу Pinterest. Запропоновано методи просування неприбуткових організацій у цій мережі, розроблено стратегії діяльності організацій. Доведено, що Pinterest буде корисним інструментом для неприбуткових організацій, оскільки вона не затратна, забезпечує постійний трасрік, легка і навіть безкоштовна у просуванні постів. Слід підкреслити, що Pinterestідеальний інструмент для молодих сайтів $i$ стартапів з обмеженим бюджетом. Ключові слова: неприбуткові організації, соціальні медіа, просування, SMM-стратегія, Pinterest, соціальні мережі.

В эпоху инфрормационных технологий социальные медиа получили статус мощ- ных, быстрых и динамичных фрорм обмена информацией. Такие социальные медиа, как Pinterest, Facebook, Twitter, используют в повседневной жизни миллиарды людей. В статье рассмотрена необходимость маркетинга в социальных медиа для неприбыльных организаций. Очерчена проблема продвижения бренда в социальных медиа. Проанализирована эфрфективность недооцененной социальной медиасети Интернет-сервиса Pinterest. Предложены методы продвижения неприбыльных организаций в этой сети, разработаны стратегии деятельности организаций. Доказано, что Pinterest будеm полезным инструментом для неприбыльных организаций, так как она не затратная, обеспечивает постоянный трафрик, легкая и даже бесплатная в продвижении постов. Следует подчеркнуть, что Pinterest - идеальный инструмент для молодых сайтов и стартапов с ограниченным бюджетом.

Ключевые слова: неприбыльные организации, социальные медиа, продвижение, SMMстратегия, Pinterest, социальные сети.

In the age of IT, social media acquired a status of fast, powerful and dynamic ways to share information. Social medias like Pinterest, Facebook, Twitter and many others, are used in everyday life by billions of people, especially youth. As a result, efficiency issues of informational potential are especially important in the context of informatization of society. In this article, I analyzed the necessity of marketing on social media for nonprofit organisations. Underlined the problem of brand promotion on social media caused by the high level of competition. During the research, I analyzed the effectiveness of underrated social media - Pinterest, that allows you to save a great amount of pictures with integrated social functions. Pinterest is not just a social media, that works differently than Facebook or Twitter, where likes are extremely valuable. The main purpose of Pinterest in contrast to other social media is SEO - account description, boards and every pin. I described benefits, gained by every non-profit organization, using SMM strategies. With a properly developed strategy, Pinterest search engine will be working excellent for B2B and B2C segments. I outlined potential methods of promoting nonprofit organizations via this social media and developed the activity strategy for this organizations. Since Pinterest users are mostly USA and Europe citizens - a solvent segment, ready for buying goods and services on social media, and the target audience of nonprofits needs these investments, it is proved that Pinterest will be a useful tool due to its inexpensiveness, providing stable traffic, easy and even free to promote posts. Pinterest marketing strategy is important for businesses of any size, in any industry. It is important to develop a strategy for a specific social network, because each has its own algorithm. Non-profit organizations should build a strategy on Pinterest, analyze and optimize it. The most important Pinterest feature for non-profit organizations is that Pinterest, unlike other social media, is future-oriented. It should be underlined that Pinterest is an ideal tool for young sites and startups with a limited budget.

Key words: non-profit organizations, social media, promotion, SMM-strategy, Pinterest, social networks.

Постановка проблеми. Есрективний та прибутковий бізнес повинен бути як офлайн, так i онлайн. Уже не один рік великою популярністю користується такий ефективний інструмент, як просування підприємства у соціальних мережах. Діяльність у соціальних мережах характерна не лише для компаній, які зосереджують роботу у мережі Інтернет. Багато підприємств, які вели свою діяльність лише офрлайн, також вибудовують стратегіï SMM (від англ. абревіатури social media marketing - маркетинг у соціальних мережах). Проте 3 кожним роком підприємствам усе складніше завойовувати прихильність користувачів, адже кожен бажає, щоб його бренд був першим у всьому, був більш упізнаваним, популярним, аніж бренд конкурентів, що зробити дуже непросто.
Тоді як усі намагаються опанувати маркетинг у соціальних мережах Facebook та Instagram (посилання на сторінки саме у цих мережах компанії найчастіше вказують на своїх вебсайтах), $є$ інші доступні, поширені й есрективні, проте недооцінені мережі. Саме такою соціальною мережею $€$ Pinterest (Пінтерест).

Аналіз останніх досліджень і публікацій. На нинішньому етапі проведено значну кількість досліджень, що присвячені проблемам залучення даного інструментарію соціальних медіа для роботи в інформаційних установах. У роботах Л. Чернявської [1] та Г. Булахової [2] представлено аналіз соціальних медіа як одного 3 елементів щодо створення позитивного іміджу і можливості рекламування власних ресурсів. Проте від часу 
заснування Pinterest (запуск бета-версії - березень 2011 р.) наукових робіт та статей про цю соціальну мережу досить мало, хоча багато інорормації можна отримати з різного роду преси. Якщо на просторах закордонних наукових видань ще можна знайти дослідження про Pinterest, то в Україні, на жаль, це складно.

Проаналізувавши доступні статті, можна сказати, що багато науковців (наприклад, К. Hansen, G. Nowlan, M. Kolind) пишуть про Pinterest як ефективний інструмент для навчальних програм у школах, вищих навчальних закладах, бібліотеках. Такі науковці, як E. Gilbert, S. Chang, L. Terveen описують статистичний огляд цієї мережі. Наукових публікацій про результативність Pinterest як інструменту просування мало.

Постановка завдання. Метою дослідження $€$ визначення:

- що таке маркетинг у соціальних медіа та навіщо він потрібен неприбутковим організаціям;

- що стимулює активність користувачів у Pinterest;

- що відрізняє цю соціальну мережу серед інших;

- як просувати неприбуткові організації у Pinterest та для яких ніш це буде найбільш еорективно.

Виклад основного матеріалу дослідження. Маркетинг у соціальних мережах - це вид Інтернетмаркетингу, метою якого $€$ активний розвиток представництва бренду відповідної організації в соціальних мережах, завоювання лояльності та залучення споживачів, а також підвищення ефективності продажів через фрормування іміджу компанії та інші інструменти соціальних мереж. Кожна неприбуткова організація формує у SMM-стратегії індивідуальні цілі, яких бажає досягти.

Застосовуючи просування у соціальних мережах, неприбуткова організація отримує основні вигоди:

1. Зв'язок зі споживачами.

За допомогою SMM організації можуть отримувати прямі відгуки від споживачів послуг (а також потенційних клієнтів), спілкуватися напряму. Інтерактивні частини у соціальних мережах через, наприклад, опитування дають можливість дізнатися про переваги чи недоліки, що варто врахувати у подальшій роботі, чого не вистачає і що потрібно споживачам.

2. Охоплення споживачів.

Охопити потенційних клієнтів за допомогою платфрорм соціальних мереж - один із найшвидших способів. Споживачам не потрібно спеціально кудись йти, щоб дізнатися про неприбуткову організацію, що надає відповідні послуги.

3. Визначення цільової аудиторії.

SMM допомагає неприбутковим організаціям за допомогою статистики відстежити інтереси своїх споживачів, їхні вподобання. Це, своєю чергою, допомагає неприбутковим організаціям визначити маркетингову стратегію загалом.

4. Лояльність споживачів до бренду.

Витрачаючи час, щоб надати підписникам у соціальних мережах корисну інфрормацію, допомогу та інтерактив, не вимагаючи нічого взамін, неприбуткова організація фрормує лояльність до свого бренду. Тоді надавачі спонсорської допомоги зможуть побачити, що їх цінують як людей, а не просто як джерело доходу.

5. Збільшення продажів.

Завдяки соціальним мережам можна залучити додатковий трафрік на вебсайт. Якщо подавати інфрормацію правильно та доступно, то користувачі, яким цікаві послуги неприбуткової організації, зможуть скористатися цією послугою, а надавачі допомоги зможуть її надати. Також можна націлювати діяльність на отримання допомоги безпосередньо на платформах соціальних мереж.

Із метою просування неприбуткової організації у соціальних медіа використовуються різні платфрорми соціальних мереж. Неприбутковим організаціям краще комплексно розвивати сторінку на декількох платформах, проте у цій статті розглянемо просування у Pinterest.

Pinterest - це соціальна мережа, візуальна пошукова система, Інтернет- та фротосервіс. Користувачі, які пройшли попередню реєстрацію, можуть завантажувати, зберігати, сортувати та керувати зображеннями, відомими у мережі як піни (від англ. pin - шпилька), та іншими медіа (наприклад, відео) через колекції, відомі як дошки (від англ. board - дошка), які створюються індивідуально.

У 2012 p. Pinterest став соціальною мережею, яка найшвидше залучала 10 млн унікальних відвідувачів щомісяця. Досягти цієї позначки мережі вдалося за два роки від запуску бета-версії. Цей рекорд досі не побила жодна інша мережа.

Станом на квітень 2020 р. Pinterest входить до топ-15 (рис. 1) соціальних медіа в усьому світі.

Варто врахувати, що на рисунку також відображено китайські соціальні мережі. Специоріка використання соціальних медіа в Китаї полягає у тому, що звичні всьому світу мережі (наприклад, Instagram, Facebook, Twitter та ін.) недоступні у цій країні. Через це там популяризуються вітчизняні соцмережі Qzone, WeChat, QQ, SinaWeibo та Kuaishou, з чого випливає: велика кількість населення + заборона світових соціальних мереж $\rightarrow$ велика кількість користувачів китайських медіа.

Pinterest постійно вдосконалюється. І3 кожним роком на маркетинг, рекламу, розробки та дослідження витрачається все більше коштів (рис. 2, 3), щоб досягти максимального задоволення користувачів, кількість яких теж із кожним роком зростає (рис. 4). 


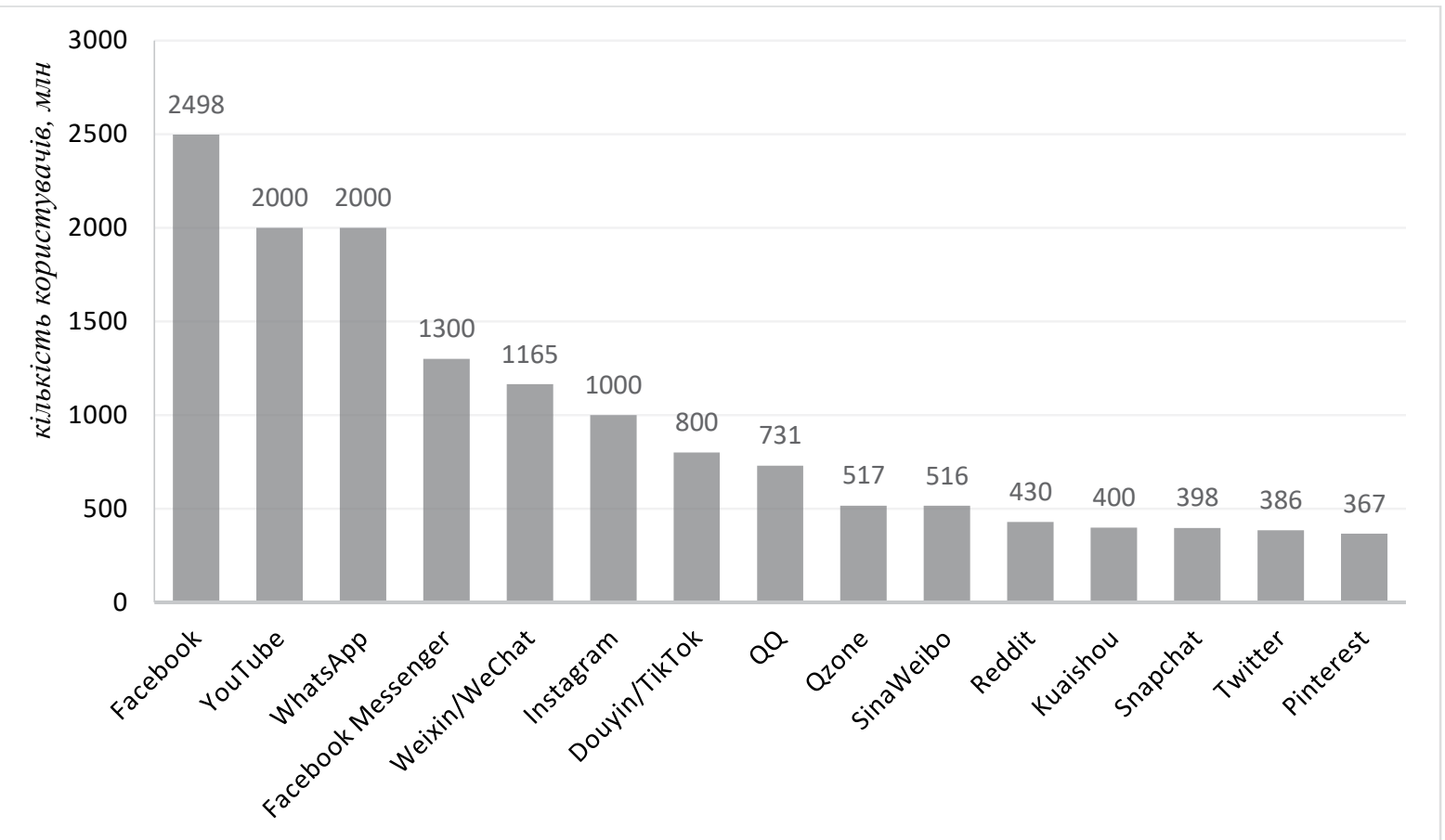

Рис. 1. Кількість активних користувачів у соціальних мережах [3]

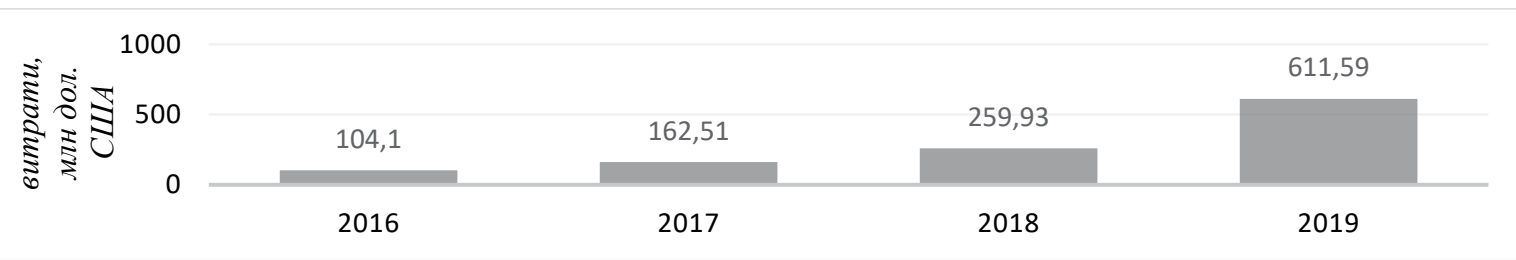

Рис. 2. Витрати Pinterest на маркетинг та рекламу [3]

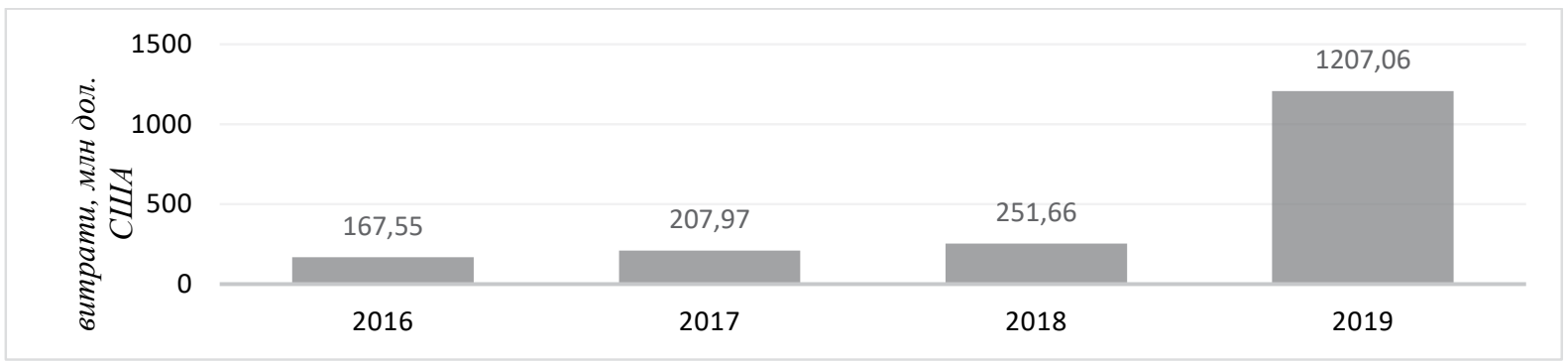

Рис. 3. Витрати Pinterest на розробки та дослідження [3]

Для кожної неприбуткової організації, підприємства така кількість відвідувачів - це число потенційних клієнтів та можливості розширити ринки збуту в усьому світі.

Pinterest як інструмент для продажу вибирають 28\% маркетологів у всьому світі. Насправді для маркетологів це одна 3 найпопулярніших платформ соціальних медіа після Facebook, Instagram, Twitter та YouTube, і це попри величезну різницю в кількості користувачів.

Одна 3 переваг, яку Pinterest має над своїми конкурентами, - це потенціал рефералів:
Pinterest приносить на 33\% більше трафріку рефрералів на вебсайти, ніж Facebook [4]. Ще вагомими перевагами мережі $є$ те, що одразу із зображенням прикріплюється активне посилання на вебсайт (на відміну від Instagram), та простий і водночас привабливий інтерфейс, зручність перегляду всіх фоото одразу з посиланням (на відміну від Facebook).

Pinterest також зацікавлений в успішному просуванні брендів і робить свій внесок у заохочення бізнесу до реклами на своїй платформі. На ньому $є$ спеціалізована сторінка з порадами для 


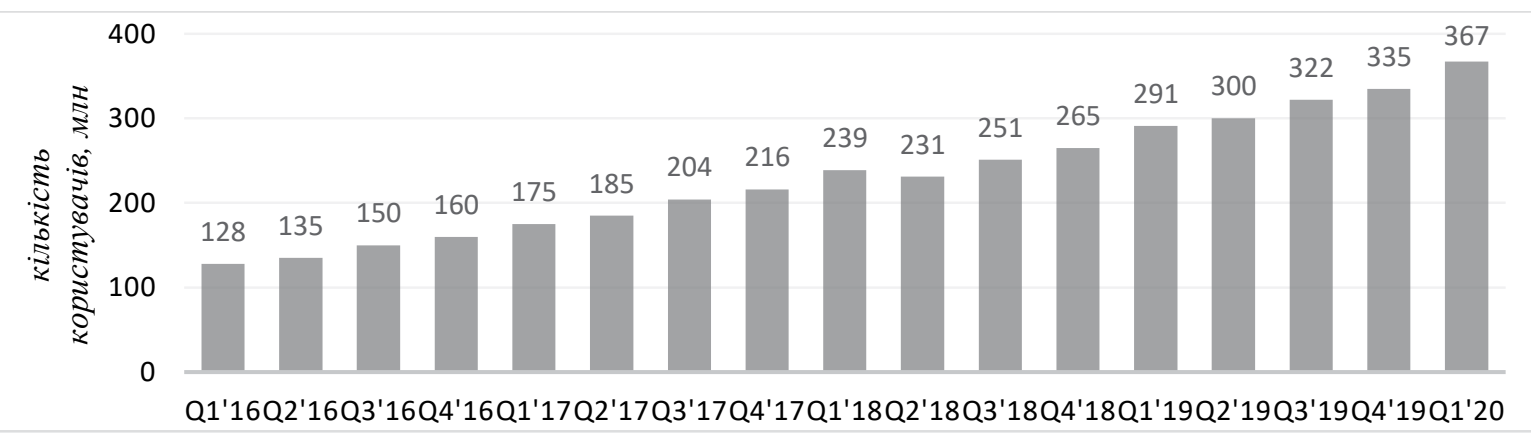

Рис. 4. Кількість користувачів Pinterest щомісяця (2016 р. - I квартал 2020 р.) [3]

підприємств, які хочуть вести свою діяльність на Pinterest.

Основою успішного просування на різних платформах $€$ створення стратегії маркетингу соціальних медіа, Pinterest не виняток. Не розуміючи цілей, цільової аудиторії та їхніх бажань, буде важко досягти результатів у соціальних медіа.

Маркетингова стратегія Pinterest має велике значення для бізнесу будь-якого розміру, в будьякій галузі. Важливо розробити стратегію саме під конкретну соціальну мережу, адже кожна має свій алгоритм.

Створення ефрективної стратегії для Pinterest передбачає такі кроки:

1. Визначення конкретних цілей, які неприбуткова організація бажає досягти.

Без конкретних цілей оцінити успіх чи рентабельність інвестицій неможливо. Наприклад, цілі можуть бути такі:

- підвищення поінформованості про бренд;

- залучення трафріку на вебсайт;

- охоплення потенційних донорів тощо.

Кожна ціль має вписуватися у рамки SMART: бути конкретною, вимірною, досяжною, відповідною та обмежена часом.

2. Визначення КРІ - ключових показників ефективності.

Основні показники ефективності повинні бути пов'язані з визначеними цілями. Наприклад:

- охоплення - кількість користувачів, які бачили пін

Перегляди публікації/Загальна кількість підписників * 100\% =охоплення публікації (\%).

- підписники - кількість користувачів, які підписались на сторінку неприбуткової організації Нові підписники/Загальна кількість підписників * * 100\% =Темп зростання аудиторії (\%)

- збереження - кількість збережень публікації на дошках користувачів

\section{Збереження/підписники $100 \%=$ = Показник збережень (\%)}

- конверсії - кількість відвідувачів вебсайту, які виконали на ньому певну дію

\author{
Конверсії/Кліки * 100\% = \\ = Коефріцієнт конверсій (\%).
}

3. Визначення цільової аудиторії (далі ЦА).

Необхідно визначити:

- ядро ЦА, пряму та непряму ЦА;

- сегментацію ЦА;

- цінності, поведінку, мислення, очікування та болі ЦА.

Розуміння цільової аудиторії допомагає зрозуміти що, як та коли поширювати в мережі.

4. Аналіз діяльності конкурентів в мережі, їхнього контенту.

Він допоможе зрозуміти, що вони роблять добре, а що ні; що очікує аудиторія та які можливості вони ще не використали.

5. Налаштування облікового запису.

Безкоштовний обліковий запис надає доступ до Pinterest Analytics та інших зручних маркетингових функцій, таких як профіль, де чітко зазначено, яка неприбуткова організація, їі діяльність, віджети Pinterest та теги Pinterest. Якщо потрібно розширити обліковий запис компанії та розмістити рекламу на Pinterest, це можна зробити, оновивши обліковий запис (створити бізнес-сторінку) і налаштувавши спосіб оплати, оскільки ця частина Pinterest не $€$ безкоштовною.

6. Вибір правильної категорії для контенту.

Вибравши правильну категорію для контенту, яким можна поділитися, піни та дошки стануть більш доступними для пошуку користувачів, які хочуть відкрити публікації, подібні у певній ніші. Користувачі можуть шукати певні категорії на Pinterest або просто перейти в розділ «Категорії» будь-якого профрілю на платорормі, щоб переглянути весь вміст, пов'язаний із темою, яку вони шукають.

7. Створення календаря публікацій.

Спільний доступ до публікацій важливий, звичайно, але не менш важливо створити план поширення контенту в мережі, щоб отримати максимальний ефект. Календар публікацій повинен включати дату та час, а також тип вмісту (фрото, відео, інфограсріка тощо) та опис.

8. Створення контенту. 
Публікації повинні бути унікальними, релевантними та доносити місію бренду. Варто спробувати правило третин:

- третина контенту просуває організацію;

- третина контенту відображає ідеї у галузі;

- третина контенту передбачає особисту взаємодію аудиторії (наприклад, через коментарі).

9. Визначення ключових слів.

Використання ключових слів у всьому профрілі, публікаціях, пінах та на дошках забезпечує бренду органічне відображення у каналах та пошуку користувачів. Ключові слова та фррази на Pinterest пов'язані з конкретними нішами, які шукають користувачі.

10. Визначення хештегів для публікацій.

Хештеги - це ключові слова та фррази, перед якими ставиться символ \# - ще один прекрасний спосіб органічного відображення для цільової аудиторії. Хештеги на Pinterest працюють так само, як і на більшості інших платформ соціальних мереж, і коли вони використовуються, роблять публікації більш зручними для пошуку.

11. Вибір методів просування в мережі.

Наприклад:

- за допомогою ключових слів та хештегів;

- реклама;

- взаємодія з іншими обліковими записами;

- поширення публікацій на платорормах інших соціальних мереж і т. д.

12. Аналіз результатів.

Аналіз результатів у Pinterest потрібен, щоб відслідковувати рефреральний трафрік, кількість залучень, охоплення потенційних клієнтів тощо, щоб визначити ступінь досягнення цілей діяльності в мережі. Найпростіший спосіб - зробити це через Pinterest Analytics.

\section{3. Удосконалення стратегії.}

На цьому етапі потрібно проаналізувати:

- наскільки неприбуткова організація стала ближчою до цілей;

- які цілі є актуальними, а які необхідно змінити;

- помилки в стратегії;

- невикористані можливості;

- шляхи оптимізації стратегії.

IKEA - один із найкращих прикладів компаній, що просувають свою діяльність у Pinterest. Компанія вирішила розповсюдити каталог у мережі, де він може по-справжньому функціонувати, крім власного вебсайту IKEA, і перенесла версію для друку на Pinterest.

Прагнучи забезпечити довший термін експлуатації каталогу, IKEA створила версію доступну для продажу, яка використовувала анкету, вбудовану в Pinterest (тобто за результатами пошуку в мережі, аналізуючи, що користувачі найбільше шукають), щоб дізнатися вподобання користувачів для створення персоналізованих дошок користувачів або дошок та продуктів рекомендацій.
За словами керівника медіапроєкту IKEA Керрі Лонгарцо, «ми не хотіли просто копіювати та вставляти - у нас вже є цифровий каталог в Інтернеті. Але просування в минулому мало відчутне становище. У нас не вистачало способів показати каталог людям в Інтернеті, тому ми шукали щось інше» [5].

Таким чином, шукаючи натхнення на Pinterest для дизайну, якщо користувач побачив меблі і вони йому сподобалися, можна не шукати, де такі придбати, а одразу перейти за посиланням та замовити.

Зручно також те, що IKEA створила декілька облікових записів, ураховуючи географрічне розповсюдження. Наприклад, IKEA USA, IKEA UK, IKEA Italia.

Висновки 3 проведеного дослідження. 3 огляду на статистику Pinterest, ігнорування потенціалу цієї платорорми, її здатність охоплювати та залучати мільйони користувачів у всьому світі - втрачені можливості росту для неприбуткових організацій.

Оскільки в Україні Pinterest лише набирає обертів, то просування у цій мережі буде ефективним для неприбуткових організацій, які не очікують збільшення продажів та прибутку, а бажають підвищити інорормативність про бренд, лояльність до компанії чи залучення трафріку на вебсайт. Для локальних компаній просування у цій мережі буде малоефективним.

Поки на українському просторі конкуренція невисока, неприбутковим організаціям варто будувати стратегію діяльності у Pinterest, проаналізувати та оптимізувати їі. Це забезпечить лідерські позиції порівняно з компаніями, які лише починають свій шлях використання цієї платорорми.

\section{БІБЛІОГРАФІЧНИЙ СПИСОК:}

1. Булахова Г. Бібліотеки в соціальних мережах та блогосфері як засіб рекламування. Наукові праці Національної бібліотеки України ім. В.І. Вернадського. 2013. Вип. 36. С. 192-199. URL: http:// nbuv.gov.ua/UJRN/npnbuimviv_2013_36_20 (дата звернення: 14.12.2020).

2. Чернявська Л. Представлення бібліотек у блогах та соціальних мережах як фрактор покращення комунікації у віртуальному середовищі. Наукові праці Національної бібліотеки України ім. B.І. Вернадського. 2013. Вип. 36. С. 200-216. URL: http://nbuv. gov.ua/UJRN/npnbuimviv_2013_36_21 (дата звернення: 14.12.2020).

3. Statista. URL: https://www.statista.com//markets/ (дата звернення: 10.01.2021).

4. Oberlo: 10 Pinterest Statistics Every Marketer Should Know in 2020. URL: https://www.oberlo.com/ blog/pinterest-statistics (дата звернення: 17.01.2021).

5. RIS: Ikea's Print Catalog Is a Hit on Pinterest. URL: https://risnews.com/ikeas-print-catalog-hit-pinterest (дата звернення: 20.12.2020). 


\section{REFERENCES:}

1. Bulakhova H. (2013) Biblioteky v sotsialnykh merezhakh ta blohosferi yak zasib reklamuvannia. [Libraries in social networks and the blogosphere as a means of advertising]. Naukovi pratsi Natsionalnoi biblioteky Ukrainy im. V.I. Vernadskoho, vol. 36 , pp. 192-199. Available at: http://nbuv.gov.ua/UJRN/ npnbuimviv_2013_36_20 (accessed 14 December 2020).

2.Cherniavska L. (2013) Predstavlennia bibliotek u blohakh ta sotsialnykh merezhakh yak faktor pokrashchennia komunikatsii u virtualnomu seredovyshchi. [Representation of libraries in blogs and social networks as a factor in improving communication in the virtual environment.] Naukovi pratsi Natsionalnoi biblioteky Ukrainy im. V.I. Vernadskoho, vol. 36, pp. 200-216. Available at: http://nbuv.gov.ua/UJRN/npnbuimviv_2013_36_21 (accessed 14 December 2020).

3. Statista. Available at: https://www.statista.com// markets/_(accessed 10 January 2021).

4. Oberlo: 10 Pinterest Statistics Every Marketer Should Know in 2020. Available at: https://www.oberlo. com/blog/pinterest-statistics (accessed 17. January 2021).

5. RIS: Ikeas Print Catalog Is a Hit on Pinterest. Available at: https://risnews.com/ikeas-print-catalog-hitpinterest (accessed 20 December 2020). 